\title{
Age-related cytokine profile in uncomplicated malaria infection
}

\author{
Youtchou Mirabeau Tatfeng, PhD¹, Dennis Edo Agbonlahor, PhD²
}

\section{SUMMARY}

Objective: Malaria infection is severe in children who are believed to be more at risk because of their relative poor immunity against the disease. Some cytokine levels (IFN- $\gamma$, IL-2, IL-4, and IL-10) of children, adolescents, and adults were assessed in this study.

Methods: Cytokine levels were assayed by using Enzyme Linked Immunosorbent Assay (ELISA). Malaria diagnosis and blood parameters were carried out by using standard parasitological and haematological techniques.

Results: The mean cytokine levels were significantly elevated in children, adolescent, and adult subjects when compared to their respective healthy controls $(\mathrm{p}<0.05)$. Also, mean IFN- $\gamma$ and IL-2 levels were significantly higher in children than in adults (IFN- $\gamma: 57.31 \pm 77.79 \mathrm{pg} / \mathrm{ml} v s .20 .37 \pm 2.95 \mathrm{pg} / \mathrm{ml}$, and IL-2: $108.75 \pm 63.53 \mathrm{pg} / \mathrm{ml} v s .66 .09 \pm 45.34 \mathrm{pg} / \mathrm{ml})(\mathrm{p}<0.05)$ and adolescents (IFN- $\gamma: 20.37 \pm 2.95 \mathrm{pg} / \mathrm{ml}$ and IL-2: $66.09 \pm 45.34 \mathrm{pg} / \mathrm{ml}$ ) respectively. Furthermore, mean IL-10 level was significantly lower in children $(7.39 \pm 15.08 \mathrm{pg} / \mathrm{ml})$ than mean level in adults $(22.73 \pm 13.89 \mathrm{pg} / \mathrm{ml})$. The mean haematological parameters revealed significant increase in total white blood cell, CD4, and CD8 count and significant decrease in the hematocrit of children in relation to adolescent and adult subjects $(\mathrm{p}<0.05)$. However, mean monocyte count was significantly higher in subjects than in their respective healthy controls $(\mathrm{p}<0.05)$.

Conclusion: Findings in this study revealed better Th1 driven immune response in children than in adolescents and adults.

Colomb Med. 2010; 41: 323-7

Keywords: Cytokine; Children; Adolescents; Adults; Falciparum malaria.

\section{Perfil de citoquina relacionado con la edad en la infección no complicada de malaria}

\section{RESUMEN}

Objetivo: La infección por malaria es grave en los niños debido a su relativa baja inmunidad contra la enfermedad. Se evaluaron en este estudio algunos niveles de citoquinas (IFN- $\gamma$, IL-2, IL-4 e IL-10) en niños, adolescentes y adultos.

Métodos: Se analizaron los niveles de citocinas mediante ensayo inmunoabsorbente ligado a enzimas (ELISA). El diagnóstico de malaria y sanguíneas se llevó a cabo utilizando las técnicas parasitológicas y hematológicas.

Resultados: Los niveles de citoquinas eran significativamente elevados en los niños, adolescentes y adultos en comparación con sus respectivos controles sanos $(\mathrm{p}<0.05)$. Además, la media de IFN- $\gamma$ y los niveles de IL-2 fueron significativamente mayores en niños que en adultos (IFN- $\gamma: 57.31 \pm 77.79 \mathrm{pg} / \mathrm{ml} v s .20 .37 \pm 2.95 \mathrm{pg} / \mathrm{ml}$ e IL-2: $108.75 \pm 63.53$ $\mathrm{pg} / \mathrm{ml} v s .66 .09 \pm 45.34 \mathrm{pg} / \mathrm{ml})(\mathrm{p}<0,05)$ y adolescentes (IFN- $\gamma: 20.37 \pm 2.95 \mathrm{pg} / \mathrm{ml}$ e IL-2: $66.09 \pm 45.34 \mathrm{pg} / \mathrm{ml})$. Por otra parte, la media de IL-10 fue significativamente menor en los niños $(7.39 \pm 15.08 \mathrm{pg} / \mathrm{ml})$ que en nivel medio en los adultos $(22.73 \pm 13.89 \mathrm{pg} / \mathrm{ml})$. La media de los parámetros hematológicos reveló un aumento significativo en la celda total de color blanco, CD4, CD8 y disminución significativa en el hematocrito de los niños en relación con los adolescentes y los adultos $(\mathrm{p}<0.05)$. No obstante, el número promedio de monocitos fue significativamente mayor en los sujetos que en sus respectivos controles sanos $(\mathrm{p}<0.05)$.

Conclusión: Los hallazgos en este estudio revelaron una mejor respuesta inmune Th1 en niños que en adolescentes y adultos.

Colomb Med. 2010; 41: 323-7

Palabras clave: Citoquinas; Niños; Adolescentes; Adultos; P. falciparum.

1. Department of Medical Laboratory Science, College of Health Sciences, Niger Delta University, Bayelsa State, Nigeria. e-mail: youtchou@yahoo.com

2. Lahor Research Laboratory, Benin City, Edo State, Nigeria. e-mail: deagbonlahor@yahoo.com

Received for publication October 22, 2009 Accepted for publication April 29, 2010 
One of the difficulties hindering the design of successful vaccine development against Plasmodium is our current incomplete knowledge of protective immunity and how it can be induced. Moreover, the pathogenesis of two of the most severe complications of $P$. falciparum malaria, cerebral malaria (CM), and severe malarial anemia (SA) appear to involve dysregulation of the immune system ${ }^{1}$. Considerable effort has been devoted to the study of the characteristics of immune responses against Plasmodium spp. Of course, much of our knowledge is based on murine experimental models. First, there is wide agreement that both cell-mediated and antibody-dependent immunity are required for adequate protection, likely encompassing different mechanisms finely tuned in time $^{2}$. Besides, innate immunity is thought to play a crucial role in clearing Plasmodium from parasitized hosts. Most of the elimination occurs in the spleen under normal circumstances, although the liver has been shown to function as an alternative clearing site ${ }^{3}$. The pathogenesis of malaria is complex and most likely entails immunologic and nonimmunologic mechanisms ${ }^{1}$. In general, it is now accepted that severe malaria is the consequence of alterations in many tissues and organs. These dysfunctions often lead to metabolic acidosis and localized ischemia. In this section, we focus on the involvement of cytokines in the immunologic mechanisms. It is evident that parasite factors can contribute to the severity of disease, as it is clear from their ability to infect a high percentage of erythrocytes ${ }^{4}$ or to induce production of proinflammatory cytokines. In particular, much evidence has been accumulated pointing to glycosylphosphatidylinositols from Plasmodium as important pathogenic factors given their ability to induce TNF- $\alpha$ and IL- $1^{5}$. This view is strongly supported by the fact that the toxicity of malarial parasite extracts can be neutralized with monoclonal antibodies against this moiety in experimental models ${ }^{6}$. It is noteworthy that recent work suggests that the presence of anti-glycosylphosphatidylinositol antibodies in patient serum may provide protection against clinical symptoms of malaria ${ }^{7}$. Therefore, cytokines, viewed as potential pathogenic elements, can contribute either directly or indirectly to many pathological processes ${ }^{8}$. Of these, control of CM and SA are critical for patient care. Although both $P$. falciparum and $P$. vivax can cause SA, only $P$. falciparum causes the many complications associated with $\mathrm{CM}^{8}$. This study aims to determine the pattern of cytokine production in relation to age of subjects.

\section{MATERIALS AND METHODS}

Study design. A total of 187 venous blood samples from subjects ( 71 children aged less than 1-10 years, 60 adolescents aged $11-18$ years, and 56 adults aged above 18 years), as well as 121 healthy controls who were slide negative (45 children aged $0-10$ years, 37 adolescents aged $11-18$ years, and 39 adults aged above 18 years) who presented symptoms of uncomplicated malaria (i.e. temperature below or equal to $39^{\circ} \mathrm{C}$, bitterness of mouth, joint pains, and lack of nervous system involvement) were collected for this study. Benin City is a cosmopolitan town located in the southsouth region of Nigeria where malaria infection is endemic. Informed consent was obtained from the patients before blood samples were collected for analysis.

Malaria parasite screening. Thick blood films were made and stained with Giemsa stain. The slides were examined for characteristic features of malaria parasites as described by Cheesbrough ${ }^{9}$.

Cytokine assay. Serum cytokine levels (IFN- $\gamma$, IL-2, IL-4, and IL-10) were assayed by using Enzyme-Linked Immunosorbent Assays (ELISA or EIA) ${ }^{10}$ reagents from MABTECH Inc. Company, Sweden.

CD4/CD8 Count. CD4 and CD8 counts were estimated by using the Dynabeads T4 -T8 Quantification Protocol (Dynal Biotech ASA, Oslo, Norway) described by the manufacturer.

Other haematological parameters. The Swelab Automatic Counter (Boule Medical Stockholm, Sweden) was used to assess the haematological parameters of the subjects and controls (packed cell volume, differential white blood cells and total white blood cells).

Statistical analysis. Statistical analysis was performed using paired t-test. $P$ values are considered significant when $\mathrm{p}<0.05$.

\section{RESULTS}

The mean cytokine levels were significantly elevated in children, adolescents, and adults when compared to 
their respective healthy controls $(\mathrm{p}<0.05)$. On the other hand, mean IFN- $\gamma$ and IL-2 levels were significantly higher in children than in adults (IFN- $\gamma$ : $57.31 \pm 77.79$ $\mathrm{pg} / \mathrm{ml} v s .20 .37 \pm 2.95 \mathrm{pg} / \mathrm{ml}$ and IL-2: $108.75 \pm 63.53$ $\mathrm{pg} / \mathrm{ml} v s .66 .09 \pm 45.34 \mathrm{pg} / \mathrm{ml})(\mathrm{p}<0.05)$. No significant difference was shown between cytokine levels under study in adolescents and those of children and adults, respectively ( $p>0.05)$. Furthermore, mean IL-10 level was significantly lower in children $(7.39 \pm 15.08 \mathrm{pg} / \mathrm{ml})$ than the mean level in adults $(22.73 \pm 13.89 \mathrm{pg} / \mathrm{ml})$.

The mean haematological parameters revealed a significant increase in total white blood cell, CD4, CD8 count and significant decrease in the packed cell volume of child subjects in relation to adolescent and adult subjects $(\mathrm{p}<0.05)$. No significant difference was obtained among subjects when mean differential cell count was considered; however, mean monocyte count was significantly higher in subjects than in their respective healthy controls $(\mathrm{p}<0.05)$ (Table 1$)$.

\section{DISCUSSION AND CONCLUSION}

The pathogenesis of malaria is complex and most likely entails immunologic and nonimmunologic mechanisms ${ }^{11}$. Cytokine imbalance has been incriminated in the complications observed in malaria infection, mostly in children for whom malaria is sometimes severe and fatal. Findings from this study revealed highly elevated levels of cytokine in subjects against their respective healthy controls. This depicts the ability of the human system to mount an effective response against malaria antigens. Further, more proinflammatory cytokine levels were higher in child subjects than their adolescent and adult counterparts. Several reports have it that these cytokines contribute in inhibiting malaria parasite replication; however, anti inflammatory response must be adequately produced to curb the activities of proinflammatory cytokine. An imbalance of this process may lead the immune system into an overdrive in its attempts to kill the parasites, and acute febrile symptoms and severe malaria can result ${ }^{12}$. Children, who are yet to develop this immunity, are, thus, at greater risk of clinical malaria, severe disease, and death than adults. Although this seems quite straightforward, it is likely to be an oversimplified view. Cerebral malaria, a common and particularly dangerous manifestation of severe malaria typically occurs in children who have already acquired a significant degree of antimalarial immunity. One potential explanation for this is that cerebral malaria is in part mediated or caused by the human immune system: the first infection 'primes' the system and reinfection leads to an overwhelming, damaging response ${ }^{12}$.

Additionally, IL-10 was significantly higher in adults than in children $(p<0.05)$. Interleukin 10 has been reported in the plasma of patients with acute malaria ${ }^{13}$. Interleukin -10 is produced by monocytes, Th2 cells, and B cells. It inhibits cytokine production in Th1 and CD8+ cells, but not in Th2 cells. Nevertheless, interleukin -10 does not affect the proliferation of Th1 and CD8+ cells, but induces B-cell proliferation, and immunoglobulin production, essential for the development and maturation of antimalarial antibodies. Interleukin- 10 seems to have an important role in defining the Thelper cell response to malaria. Moreover, interleukin- 10 down regulates MHC class II molecules on macrophages, leading to decreased antigen presentation $^{14}$, inhibits ROI and NOI production, prevents $\mathrm{T}$ cell priming and proliferation, and suppresses the production of interferon, interleukin 6, Tumor Necrosis Factor- $\alpha$ (TNF- $\alpha$ ), and GM-CSF by T cells. The inhibition of IFN- $\gamma$ and TNF- $\alpha$ secretion by IL-10 synthesis has been reported important to counteract the pathological role of macrophages in cerebral malaria ${ }^{15}$. A study of malaria-infected children and adults in Gabon recorded many IL-10-producing CD4+ and CD8+ T cells co-expressing interferon. These cells may provide a fertile ground for parasite-driven immune modulation. It was shown that the increase of IL-10 is more pronounced and more specific than IL- 6 and interleukin 8 in patients with malaria parasitaemia compared to other infections ${ }^{16}$. However, it is not yet clear whether the increased concentrations of interleukin -10 have a beneficial role by reducing the parasite-induced inflammatory response, or a detrimental one by decreasing the cellular immune responses. Nevertheless, it has been shown that severe anaemia is associated with reduced concentrations of circulating interleukin and an increased ratio between TNF- $\alpha$ and interleukin -10 contributes to the reversible bone-marrow suppression seen in malaria patients ${ }^{17}$. Furthermore, a prominent role in switching from $T h 1$ to $T h 2$ responses is attributed to IL-10; therefore, it is probably involved in controlling 


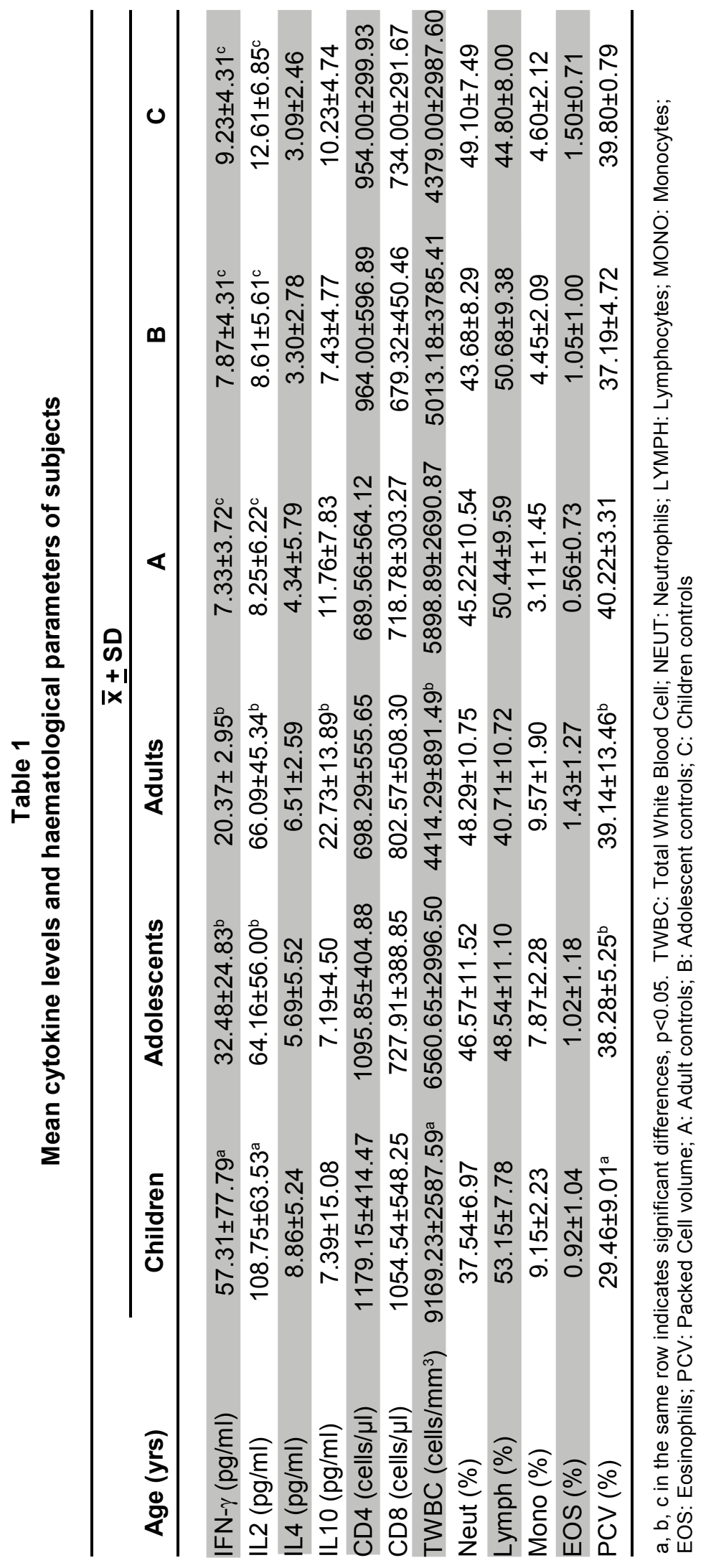

the adequate timing of antiparasitic responses. Early IL-10 production has been associated with susceptibility to infection ${ }^{18}$, and it is thought that this cytokine has a prominent antiinflammatory effect, somehow limiting the damage inflicted on normal tissues by excessive Th1 response. Haematological indices showed a higher total white blood cell count in child subjects with an elevated differential monocyte count, which obviously indicates an attempt by the human system to combat the foreign malaria antigens.

In conclusion, in the past years, many studies concentrated on the role of cytokines in the pathophysiology and protection against malaria fever. First, both type 1 and type 2 cytokines are required for adequate protection, likely encompassing different mechanisms finely tuned in time and intensity. Type 1 cytokines are important in controlling early parasitaemia, although they need to be counterbalanced later in the infection by a type- 2 response, which leads to antibody production. Second, pathogenesis of malaria is a complex process in which a common outcome might be reached by different routes ${ }^{19}$. However, this study shows a Th1-driven response in children.

Conflict of interest. None of the authors has conflicts of interest related to this study.

\section{REFERENCES}

1. Miller LH, Baruch DI, Marsh K, Doumbo OK. The pathogenic basis of malaria. Nature. 2002; 415 : 673-89.

2. Mohan K, Stevenson MM. Acquired immunity to asexual blood stages in malaria. In: IW Sherman (ed.). Parasite biology, pathogenesis, and protection. Washington, DC: ASM Press; 1998. p. 467-73.

3. Dockrell HM, De Souza JB, Playfair JH. The role of the liver in immunity to blood-stage murine malaria. Immunology. 1980; 41: 421-30.

4. Chotivanich K, Udomsangpetch R, Dondorp A, Williams T, Angus B, Simpson JA, et al. The mechanisms of parasite clearance after antimalarial treatment of Plasmodium falciparum malaria. $J$ Infect Dis. 2000; 182: 629-33.

5. Schofield L, Hackett F. Signal transduction in host cells by a glycosylphosphatidylinositol toxin of malaria parasites. J Exp Med. 1993, 177:145-53. 


\section{Colombia Médica}

6. Schofield L, Vivas L, Hackett F, Gerold P, Schwarz RT, Tachado S. Neutralizing monoclonal antibodies to glycosylphosphatidylinositol, the dominant TNF-alpha-inducing toxin of Plasmodium falciparum: prospects for the immunotherapy of severe malaria. Ann Trop Med Parasitol. 1993; 87: 617-26.

7. Naik RS, Branch OH, Woods AS, Vijaykumar M, Perkins DJ, Nahlen BL, et al. Glycosylphosphatidylinositol anchors of Plasmodium falciparum: molecular characterization and naturally elicited antibody response that may provide immunity to malaria pathogenesis. J Exp Med. 2000; 192: 1563-66.

8. Clark IA, Schofield L. Pathogenesis of malaria. Parasitol Today. 2000; 16: 451-54.

9. Cheesbrough M. Malaria parasites. In: Medical laboratory manual for tropical countries. Vol. II. $2^{\text {nd }}$ ed. London: Tropical Health Technology; 1992. p. 221-5.

10. Baron EJ, Peterson LR, Finegold FS. Immunodiagnosis. In: James FS, Potts LM, Chris M, Julie T, (eds.). Diagnostic microbioly. $9^{\text {th }}$ ed. London: Mosby; 1994. p. 134-5.

11. Miller LH, Baruch DI, Marsh K, Doumbo OK. The pathogenic basis of malaria. Nature. 2002; 415: 673-79.

12. Riley E. Malaria and people. Wellcome trust. [accessed on the 20/05/2009]. URL: http://www.wellcome.ac.uk/; 2005.

13. Wenish C, Parschalk B, Narzt E, Looareesuwan S, Graninger

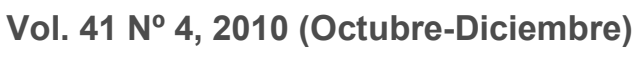

W. Elevated serum levels of interleukin-10 and IFN-gamma in patients with acute Plasmodium falciparum malaria. Clin Immunol Immunopathol. 1995; 74: 115-7.

14. Akdis CA, Blaser K. IL-10-induced anergy in peripheral T cell and reactivation by microenvironmental cytokines: two key steps in specific immunotherapy. FASEB J. 1999; 19: 603-9.

15. Kossodo S, Monso C, Juillard P, Velu T, Goldman M, Grau GE. Interleukin-10 modulates susceptibility in experimental cerebral malaria. Immunology. 1997; 91: 536-40.

16. Jason J, Archibald LK, Nwanyanwu OC. Cytokines and malaria parasitemia. Clin Immunol. 2001; 100: 208-18.

17. Othoro C, Lal AA, Nahlen B, Koech D, Orago AS, Udhayakumar VA. Low IL-10 tumor necrosis factoralpha ratio is associated with malaria anemia in children residing in a holoendemic malaria region in western Kenya. $J$ Infect Dis. 1999; 179: 279-82.

18. Yoshida A, Maruyama H, Kumagai T, Amano T, Kobayashi F, Zhang M, et al. Schistosoma mansoni infection cancels the susceptibility to Plasmodium chabaudi through induction of type 1 immune responses in A/J mice. Int Immunol. 2000; 12 : 1117-25.

19. Inigo A, Manuel F. Cytokines in the pathogenesis of and protection against malaria. Clin Diag Lab Immunol. 2002; 9: 1145-52. 